\title{
ANALISIS KOMPARATIF PENDAPATAN USAHATANI KENTANG VARIETAS SUPERJOHN DAN VARIETAS GRANOLA L DI DESA PINASUNGKULAN UTARA KECAMATAN MODOINDING
}

\author{
Neni Nuraeni \\ Rine Kaunang \\ Lorraine W. Th. Sondak
}

\begin{abstract}
The objective of this research is to know the comparison of Superjohn varieties and varieties of Granola L in Pinasungkulan Utara Village, Modoinding District. The location of the study was determined purposively (purposive sampling), the determination of the number of samples taken by census (Saturated Sampling) for farmers varieties Granola L as much as 20 farmers and 20 farmers Superjohn varieties taken simple random (Simple Random Sampling). The method of analysis used in this research is the analysis of farm income and komaparatif analysis by using t-test two samples Independent Sample T-test. The results showed that the average income of farmers Superjohn varieties is Rp.70.062.947,00 lower than the average income obtained by farmers varieties Granola L Rp.87.029.058,00. It can be seen that the average income difference between the two varieties is Rp.16.960.111,00. Based on statistical test results with MINITAB Program, the calculation of income per hectare obtained significant value of $P$-Value of 0.01 at $\alpha 5 \%$ that is $0,01<0,05$. This means that $H_{0}$ is rejected and $H_{1}$ is tested for the fact that there is a significant difference between Superjohn varieties potato production income and Granola L varieties.
\end{abstract}

Keywords: comparative analysis, income of potato farming, North Pinasungkulan Village, Modoinding Sub-district.

\begin{abstract}
ABSTRAK
Penelitian ini bertujuan untuk mengetahui perbandingan pendapatan usahatani kentang varietas Superjohn dan varietas Granola $L$ di Desa Pinasungkulan Utara Kecamatan Modoinding. Lokasi penelitian ditentukan secara sengaja (Purposive Sampling), penentuan jumlah sampel diambil secara sensus (Sampling Jenuh) untuk petani varietas Granola $L$ sebanyak 20 petani dan 20 petani varietas Superjohn diambil secara acak sederhana (Simple Random Sampling). Metode analisis yang digunakan dalam penelitian ini yaitu analisis pendapatan usahatani dan analisis komaparatif dengan menggunakan t-uji dua sampel Independent Sample T-test. Hasil penelitian menunjukkan bahwa rata-rata pendapatan petani varietas Superjohn adalah Rp.70.062.947,00 lebih rendah dibandingkan dengan rata-rata pendapatan yang diperoleh petani varietas Granola $L$ sebesar Rp.87.029.058,00. Dapat dilihat bahwa rata-rata selisih pendapatan yang diperoleh antara kedua varietas adalah sebesar Rp.16.960.111,00. Berdasarkan hasil uji statistik dengan Program MINITAB, perhitungan pendapatan per hektar diperoleh nilai signifikan P-Value sebesar 0,01 pada $\alpha 5 \%$ yaitu $0,01<$ 0,05. Hal ini berarti $\mathrm{H}_{0}$ ditolak dan $\mathrm{H}_{1}$ teruji kebenarannya bahwa ada perbedaan pendapatan antara usahatani kentang varietas Superjohn dan varietas Granola $L$.
\end{abstract}

Kata kunci: analisis komparatif, pendapatan usahatani kentang, Desa Pinasungkulan Utara, Kecamatan Modoinding. 


\section{PENDAHULUAN}

\section{Latar Belakang}

Komoditi holtikultura di Indonesia merupakan salah satu produk pertanian yang dapat dikembangkan untuk meningkatkan pendapatan petani. Salah satu komoditi pertanian yang dapat membantu meningkatkan pendapatan dan kesejahteraan petani adalah kentang (Solanum tuberosum L).

Kentang (Solanum tuberosum L). Kentang adalah komoditas sayuran dengan kegunaan ganda, yaitu sebagai sayuran dan substitusi karbohidrat. Kentang digunakan sebagai makanan olahan, usaha rumah tangga, restoran siap saji, sampai industri besar untuk pembuatan tepung dan keripik. Pasar kentang bukan hanya di dalam negeri, tetapi juga di luar negeri sebagai komoditas ekspor yang menguntungkan (Duriat, 2006).

\begin{tabular}{|c|c|c|c|c|}
\hline Desa & $\begin{array}{c}\text { Luas } \\
\text { Tanam } \\
\text { (Ha) }\end{array}$ & $\begin{array}{c}\text { Luas } \\
\text { Panen } \\
\text { (Ha) }\end{array}$ & $\begin{array}{c}\text { Produktifitas } \\
\text { (Ton) }\end{array}$ & $\begin{array}{c}\text { Total } \\
\text { Produksi }\end{array}$ \\
\hline Mokobang & 25 & 20 & 20 & 400 \\
\hline Wulurmaatus & 26 & 30 & 20 & 600 \\
\hline Palelon & 25 & 26 & 20 & 520 \\
\hline Makaaruyen & 29 & 34 & 20 & 680 \\
\hline Pinasungkulan & 26 & 33 & 20 & 660 \\
\hline Pinasungkulan Utara & 27 & 30 & 20 & 600 \\
\hline Linelean & 28 & 31 & 20 & 620 \\
\hline Sinisir & 25 & 32 & 20 & 640 \\
\hline Kakenturan & 25 & 26 & 20 & 520 \\
\hline Kakenturan Barat & 20 & 28 & 20 & 560 \\
\hline Jumlah & 256 & 290 & & 5800 \\
\hline
\end{tabular}

Kecamatan Modoinding adalah salah satu kecamatan yang ada di Kabupaten Minahasa Selatan Provinsi Sulawesi Utara. Pertanian menjadi sektor andalan penduduk Kecamatan Modoinding sebagai sumber penghasilan utama sebagian besar penduduknya. Tabel 1 menunjukkan bahwa Desa Pinasungkulan Utara merupakan salah satu desa sentra produksi kentang, dimana hanya di desa ini petani kentang menggunakan benih varietas Superjohn dan varietas Granola $L$.

Kentang varietas Superjohn dan varietas Granola $L$ merupakan turunan dari kentang varietas Granola. Kentang varietas Granola yaitu kentang yang dilepas oleh Balai Penelitian Tanaman Sayuran (Balitsa), kentang varietas Granola berdaya hasil tinggi, umur pendek, dan memiliki adaptasi yang luas, serta toleran terhadap serangan layu bakteri. Oleh karenanya, varietas Granola merupakan satu-satunya varietas yang mendominasi produksi kentang di Indonesia, yaitu mencapai areal tanam 90\% lebih (Basuki et al. 2005 dalam Ridwan, 2010). Sedangkan kentang varietas Superjohn adalah kentang yang ditemukan oleh John Walukow sehingga kentang ini telah lama di budidayakan di Wilayah Modassi (Modoinding, Modayag dan Passi). tetapi bibit kentang varietas Granola $L$ masih sangat terbatas. Oleh sebab itu, petani kentang yang ada di Desa Pinasungkulan Utara masih bertahan dengan kentang varietas Superjohn. Selain itu, masih adanya permintaan kentang Superjohn dari konsumen karena bentuknya yang cukup besar.

Berdasarkan uraian di atas, maka penulis tertarik untuk melakukan penelitian dengan judul "Analisis Komparatif Pendapatan Usahatani Kentang Varietas Superjohn dan Varietas Granola $L$ di Desa Pinasungkulan Utara Kecamatan Modoinding”

\section{Perumusan Masalah}

Berdasarkan uraian latar belakang yang dikemukakan, maka rumusan masalah dalam penelitian ini adalah Berapakah perbandingan pendapatan usahatani kentang varietas Superjohn dan varietas Granola $L$ di Desa Pinasungkulan Utara Kecamatan Modoinding.

\section{Tujuan Penelitian}

Tujuan dari penelitian ini yaitu untuk mengetahui perbandingan pendapatan usahatani kentang varietas Superjohn dan varietas Granola $L$ di Desa Pinasungkulan Utara Kecamatan Modoinding.

\section{Manfaat Penelitian}

Penelitian ini diharapkan dapat memberikan informasi dan masukan pada petani dalam pemilihan varietas benih kentang yang lebih baik agar diperoleh produksi yang tinggi sehingga mampu meningkatkan pendapatan dan keuntungan usahatani. Bagi pemerintah, diharapkan penelitian ini dapat menjadi masukan dalam penentuan dan penetapan kebijakan yang berhubungan dengan usahatani kentang khususnya dan sektor 
pertanian umumnya. Penelitian ini juga diharapkan dapat memberikan informasi dan referensi bagi penelitian selanjutnya.

\section{METODOLOGI PENELITIAN}

\section{Waktu dan Tempat Penelitian}

Penelitian ini dilakukan di Desa Pinasungkulan Utara Kecamatan Modoinding Kabupaten Minahasa Selatan. Penelitian ini berlangsung selama tiga bulan dengan waktu penelitian dari bulan Oktober sampai Desember 2017 dimulai dari pengumpulan data sampai dengan penyusunan laporan hasil penelitian.

\section{Metode Pengumpulan Data}

Data yang digunakan dalam penelitian ini adalah data primer dan data sekunder. Data primer diperoleh melalui metode wawancara dengan menggunakan daftar pertanyaan (kuesioner) kepada para petani di Desa Pinasungkulan Utara. Data sekunder diperoleh dari instansi-instansi yang terakit dalam penelitian ini seperti BP3K Kecamatan Modoinding dan Kantor Kecamatan Modoinding.

\section{Metode Pengambilan Sampel}

Pengambilan sampel dalam penelitian ini dilakukan dalam dua tahap. Pertama adalah menentukan sampel Desa Pinasungkulan Utara yang diambil secara sengaja (Purposive Sampling). Kedua, sampel ditarik dari dua populasi petani kentang Desa Pinasungkulan Utara yang terdiri dari 20 petani varietas Granola $L$ dan 100 petani varietas Superjohn. Sampel yang diambil sebagai responden hanya petani yang memiliki lahan milik sendiri, tidak sewa ataupun bagi hasil. Selanjutnya jumlah sampel diambil secara sensus (Sampling Jenuh) untuk petani varietas Granola $L$ sebanyak 20 petani dan 20 petani varietas Superjohn diambil secara acak sederhana (Simple Random Sampling).

\section{Konsepsi Pengukuran Variabel}

A. Gambaran Umum Responden

1. Umur (tahun)

2. Tingkat pendidikan (SD, SMP, SMA, Perguruan Tinggi)

3. Lamanya berusahatani kentang (tahun)

B. Variabel Pokok

1. Luas lahan, yaitu luas lahan yang ditanami kentang (ha)

2. Status dan kepemilikan lahan, adalah milik sendiri atau bukan milik sendiri (sewa, bagi hasil dan lain-lain)

3. Biaya produksi yaitu biaya yang dikeluarkan petani selama proses produksi kentang selama satu kali panen

$$
\begin{aligned}
& \text { a. Biaya tetap ; } \\
& \text { - } \text { Pajak (Rp/thn) } \\
& \text { - } \text { Biaya penyusutan alat (Rp), } \\
& \text { dihitung menggunakan } \\
& \text { "Straight Line Method" } \\
& \text { dengan formulasi: } \\
& \boldsymbol{\rho}=\frac{\mathbf{N b}-\mathbf{N s}}{\mathbf{n}} \\
& \text { Dimana, } \mathrm{Nb}=\text { Nilai Baru } \\
& \mathrm{Ns}=\text { Nilai Sisa } \\
& \mathrm{N}=\text { Jangka Usia Ekonomis }
\end{aligned}
$$

b. Biaya tidak tetap (biaya variabel)

- Tenaga kerja (Rp/HOK)

- Benih, yaitu banyaknya benih yang digunakan oleh petani dalam usahataninya $(\mathrm{Rp} / \mathrm{kg})$

- Pupuk, yaitu banyaknya pupuk yang digunakan oleh petani dalam usahatani nya $(\mathrm{Rp} / \mathrm{kg})$

- Pestisida, yaitu banyaknya pestisida yang digunakan olah petani dalam usahataninya ( Rp/kg)

- Transportasi (Rp/hari)

4. Jumlah produksi kentang dalam satu kali panen (ton/ha)

5. Harga jual, yaitu harga yang berlaku di tingkat petani $(\mathrm{Rp} / \mathrm{kg})$

6. Penerimaan adalah perkalian antara produksi dengan harga jual ( $\mathrm{Rp} / \mathrm{kg})$.

7. Pendapatan, selisih antara penerimaan dan pengeluaran $(\mathrm{Rp})$. 


\section{Metode Analisis Data}

\section{Analisis Pendapatan Usahatani}

a. Biaya Produksi

$$
\mathrm{TC}=\mathrm{FC}+\mathrm{VC}
$$

Dimana $: \mathrm{TC}=$ Total Cost $($ total biaya)

$$
\begin{aligned}
& \mathrm{FC}=\text { Fixed Cost }(\text { biaya tetap) } \\
& \mathrm{VC}=\text { Variable Cost } \text { (biaya tidak } \\
& \text { tetap) }
\end{aligned}
$$

b. Penerimaan

$$
\mathrm{TR}=\mathrm{TP} \times \mathrm{P}
$$

Dimana $: \mathrm{TR}=$ Total Revenue $($ total penerimaan)

$\mathrm{TP}=$ Total Production (total produksi)

$\mathrm{P}=$ Price (harga)

c. Pendapatan

$$
\mathrm{I}=\mathrm{TR}-\mathrm{TC}
$$

Dimana $: \mathrm{I}=$ Income (pendapatan),

$\mathrm{TR}=$ Total Revenue (total penerimaan),

$\mathrm{TC}=$ Total Cost $($ total biaya $)$.

\section{Analisis Komparatif}

Analisis komparatif bertujuan untuk membandingkan kondisi antara dua kelompok. Penelitian ini menggunakan t-uji dua variabel bebas dan perhitungan menggunakan program MINITAB (Sugiyono, 2010).

$$
t=\frac{\bar{x}_{1}-\bar{x}_{2}}{\sqrt{\frac{s_{1}{ }^{2}}{n_{1}}+\frac{s_{2}}{n_{2}}-2 r\left(\frac{s_{1}}{\sqrt{n_{1}}}\right)\left(\frac{s_{2}}{\sqrt{n_{2}}}\right)}}
$$

Dimana, $\mathrm{t}=$ nilai korelasi $\mathrm{x} 1$ dengan $\mathrm{x} 2$

$\mathrm{n}=$ jumlah sampel

$\mathrm{x}=$ rata-rata sampel ke 1

$\mathrm{x}=$ rata-rata sampel ke 2

s1 = standar deviasi sampel ke 1

s2 = standar deviasi sampel ke 2

$\mathrm{S} 1=$ varians sampel ke 1

S2 = varians sampel ke 2

Dengan Hipotesis :

a. Hipotesis (H0) diterima jika nilai sig. (2-tailed) $>0,05$ berarti tidak terdapat perbedaan pendapatan usahatani kentang varietas Superjohn dan varietas Granola L b. Hipotesis (H1) diterima jika nilai sig. (2-tailed) $<0,05$ berarti bahwa terdapat perbedaan pendapatan usahatani kentang varietas Superjohn dan varietas Granola L

\section{HASIL DAN PEMBAHASAN}

\section{Deskripsi Lokasi Penelitian}

\section{Keadaan Geografis}

Desa Pinasungkulan Utara berada di Kecamatan Modoinding yang merupakan salah Satu Kecamatan yang ada di Kabupaten Minahasa Selatan, yang mempunyai batas-batas wilayah sebagai berikut :
a. Sebelah Utara dengan Desa Makaaroyen/Desa Palelon
b. Sebelah Selatan dengan Desa Pinasungkulan
c. Sebelah Barat dengan Desa Makaaroyen
d. Sebelah Timur dengan Desa Linelean

\section{Letak dan Keadaan Iklim}

Secara geografis Desa Pinasungkulan Utara adalah salah satu desa di daerah pegunungan Minahasa Selatan dengan ketinggian $\pm 1100 \mathrm{M}$ di atas permukaan laut. Desa Pinasungkulan Utara memiliki iklim musim (muson), seperti halnya daerah Minahasa lainnya yang dipengaruhi oleh angin muson. Pada bulan November sampai April bertiup angin laut yang basah dan menimbulkan hujan dan pada bulan Mei sampai Oktober bertiup angin barat yang kering dan akan menimbulkan musim kemarau. Suhu rata-rata perbulan di desa ini minimum antara $17-23^{\circ} \mathrm{C}$ dan maksimum antara $25-31^{\circ} \mathrm{C}$ dengan curah hujan pertahun rata-rata $2.279 \mathrm{~mm}$ dan perbulan rata-rata $189,9 \mathrm{~mm}$. Kecepatan angin minimum 2 knot/jam dan maksimum 10 knot/jam.

\section{Penduduk}

Jumlah penduduk yang ada di Desa Pinasungkulan Utara yaitu sebanyak 525 jiwa laki-laki dan 496 jiwa perempuan, total 1021 jiwa dengan jumlah kepala keluarga 310. Penduduk yang ada di Desa Pinasungkulan Utara merupakan pemasok hortikultura yang 
dipasarkan di beberapa daerah di Indonesia Timur, seperti Sulawesi Tengah, Sulawesi Selatan, Gorontalo, Maluku, Maluku Utara, Papua bahkan sampai di Kalimantan seperti Balikpapan dan Samarinda. Hal ini karena sebagian besar penduduk bermata pencaharian sebagai petani.

\section{Karakteristik Responden}

\section{Umur}

Umur akan mempengaruhi produktifitas dalam bekerja dan dalam proses pengambilan keputusan diberbagai pekerjaan yang dilakukan. Menurut hasil penelitian yang dilakukan di Desa Pinasungkulan Utara, umur responden dapat dilihat pada Tabel 2.

\begin{tabular}{|c|c|c|c|c|c|}
\hline \multirow{2}{*}{ No } & \multirow{2}{*}{ Umur (Tahun) } & \multicolumn{2}{|c|}{ Jumlah Responden (Orang) } & \multicolumn{2}{|c|}{ Persentase (\%) } \\
\hline & & Superjohn & Granola L & Superjohn & Granola L \\
\hline 1 & $\leq 30$ & 2 & 1 & 10 & 5 \\
\hline 2 & $31-40$ & 6 & 7 & 30 & 35 \\
\hline 3 & $41-50$ & 4 & 7 & 20 & 35 \\
\hline \multirow[t]{2}{*}{4} & $>50$ & 8 & 5 & 40 & 25 \\
\hline & Jumlah & 20 & 20 & 100 & 100 \\
\hline
\end{tabular}

Tabel 2 menunjukkan jumlah responden petani varietas Superjhon dan varietas Granola $L$. Dapat dilihat bahwa petani varietas Superjohn cukup banyak responden yang berumur lebih dari 50 tahun, sedangkan petani benih varietas Granola $L$ lebih banyak responden yang berumur di bawah 50 tahun. Hal ini karena petani yang berumur lebih dari 50 tahun sudah lama menggunakkan benih varietas Superjohn, selain itu masih adanya permintaan dari pemborong untuk kentang varietas Superjohn. sedangkan petani granola 1 yang berumur di bawah 50 banyak menggunakkan varietas Granola $L$ karena awalnya ingin mencoba benih baru, kemudian setelah produksi meningkat petani memilih untuk bertahan menggunakan benih ini.

\section{Tingkat Pendidikan}

Peran pendidikan formal sangat penting dalam usaha peningkatan kualitas penduduk dan peningkatan intelektual serta wawasan seseorang. Berdasarkan hasil penelitian, tingkat pendidikan responden sangat bervariasi. Hal tersebut dapat dilihat pada Tabel 3.

\begin{tabular}{llcccc}
\multicolumn{2}{c}{ Tabel 3. Jumlah Responden Menurut Tingkat Pendidikan } \\
\hline \multirow{2}{*}{ No } & \multirow{2}{*}{ Tingkat Pendidikan } & \multicolumn{2}{c}{$\begin{array}{c}\text { Jumlah Responden } \\
\text { (Orang) }\end{array}$} & \multicolumn{2}{c}{ Persentase (\%) } \\
\cline { 3 - 6 } & & 1 & - & 5 & - \\
\cline { 3 - 6 } & Superjohn & Granola L & Superjohn & Granola L \\
\hline 1 & SD & 3 & 6 & 15 & 30 \\
2 & SLTP & 16 & 13 & 80 & 65 \\
3 & SLTA & - & 1 & - & 5 \\
\hline & S1 & 20 & 20 & 100 & 100 \\
\hline & Jumlah & & & &
\end{tabular}

Pada Tabel 3 menunjukkan tingkat pendidikan responden petani benih varietas Superjohn, dimana responden terbanyak yaitu SLTA dengan persentase $80 \%$, kemudian SLTP dengan persentase $15 \%$ dan terakhir SD dengan persentase $5 \%$. Untuk petani benih varietas Granola $L$, jumlah responden terbanyak yaitu SLTA dengan persentase $65 \%$, kemudian jumlah responden SLTP dengan persentase $30 \%$ dan S1 dengan persentase 5\%. Tingkat pendidikan petani varietas Superjohn dan Granola $L$ rata-rata sama, banyak petani lulusan SLTA.

\section{Lamanya Berusahatani}

Cara berusahatani seseorang sebagian besar dipengaruhi oleh lamanya berusahatani, karena semakin lama melakukan usahatani tersebut semakin dalam pengetahuan serta semakin luas wawasan petani terhadap usahatani yang dijalankan. Berikut jumlah responden menurut lamanya berusahatani, dapat dilihat pada Tabel 4.

Tabel 4. Jumlah Responden Menurut Pengalaman Berusahatani

\begin{tabular}{cccccc}
\hline \multirow{2}{*}{ No } & $\begin{array}{c}\text { Lamanya } \\
\text { Berusahatani } \\
(\text { Tahun) }\end{array}$ & \multicolumn{2}{c}{ Jumlah Responden (Orang) } & \multicolumn{2}{c}{ Persentase (\%) } \\
\cline { 3 - 6 } & Superjohn & Granola L & Superjohn & Granola L \\
\hline 1 & $1-10$ & 1 & 2 & 5 & 10 \\
2 & $11-20$ & 12 & 11 & 60 & 55 \\
3 & $21-30$ & 7 & 7 & 35 & 35 \\
\hline \multicolumn{2}{c}{ Jumlah } & 20 & 20 & 100 & 100 \\
\hline
\end{tabular}

Tabel 4 menunjukkan tingkat lamanya berusahatani petani varietas Superjohn, dimana jumlah terbanyak pada 11-20 tahun dengan persentase 60\%, kemudian 21-30 tahun sebanyak 7 petani dengan persentase $35 \%$ dan kurang dari 10 tahun hanya $5 \%$. Sedangkan petani benih varietas Granola $L$ 
terbanyak yaitu pada 11-20 tahun dengan persentase sebesar 55\%, 21-30 tahun memiliki persentase sebesar $35 \%$ dan kurang dari 10 tahun sebesar $10 \%$.

\section{Status Penguasaan Lahan}

Berdasarkan hasil penelitian, status penguasaan lahan petani kentang varietas Superjohn dan varietas Granola $L$ di Desa Pinasungkulan Utara Kecamatan Modoinding yaitu milik sendiri, tidak sewa ataupun bagi hasil.

\section{Luas Lahan}

Secara umum luas lahan sangat mempengaruhi jumlah produksi yang akan dihasilkan dengan begitu juga mempengaruhi pendapatan petani. Berdasarkan hasil penelitian, luas lahan yang di usahakan oleh petani kentang varietas Superjohn dan varietas Granola $L$ rata-rata yaitu 1 hektar untuk tanaman kentang dan lahan lainnya di usahakan untuk sayuran jenis lain seperti sawi, kol, labu, bawang merah, kubis, wortel dan batang bawang. Hal ini karena banyaknya permintaan dari pemborong kentang seperti pasar lokal yaitu Bitung, Manado dan Tondano. Bahkan permintaan pemborong dari luar pulau Sulawesi Utara seperti dari Papua yaitu Sorong dan Timika, Maluku Utara yaitu Ambon dan Ternate, Sulawesi Tengah yaitu Luwuk dan Palu, Jakarta Timur pada Pasar Kramat Jati, Jawa Barat yaitu Cibitung, Kalimantan yaitu Samarinda dan Balikpapan, dan Makassar yaitu ujung Pandang. Selain itu, benih/bibit yang disediakan oleh petani kentang varietas Superjohn dan Granola $L$ untuk lahan 1 hektar karena bibit yang diperoleh dari hasil produksi sebelumnya yaitu kentang kecil yang dijadikan bibit.

\section{Produksi, Biaya Produksi, Penerimaan dan Pendapatan Petani per Hektar}

Biaya produksi adalah keseluruhan biaya yang digunakan dalam satu kali proses produksi. Biaya produksi meliputi biaya tetap yaitu biaya pajak, biaya penyusutan alat, sewa lahan. Dan biaya tidak tetap yaitu benih, pupuk, bahan bakar, biaya angkut, pestisida dan biaya tenaga kerja. Rata-rata biaya produksi dari hasil penelitian dapat dilihat pada Tabel 5.

\begin{tabular}{llcc}
\multicolumn{4}{l}{ Tabel 5. Rata-rata Biaya Produksi Per Hektar } \\
\hline No & \multicolumn{1}{c}{ Jenis Biaya } & Superjohn (Rp) & Granola L (Rp) \\
\hline 1. & Benih/bibit & $700.000,00$ & $700.000,00$ \\
2. & Pajak & $17.000,00$ & $12.750,00$ \\
& Pengolahan Lahan : & \\
& Sewa Alat & $1.350 .000,00$ & $1.332 .500,00$ \\
& Pupuk : & & \\
Urea & $411.250,00$ & $476.250,00$ \\
SP36 & $1.815 .357,00$ & $1.794 .167,00$ \\
Belarusia & $2.949 .166,00$ & $2.521 .875,00$ \\
Organik & $1.258 .333,00$ & $1.692 .000,00$ \\
Phonska & $1.916 .947,00$ & $1.925 .250,00$ \\
3. Pestisida & $342.250,00$ & $463.900,00$ \\
4. Tenaga Kerja : & & \\
& Pengolahan Lahan & $2.945 .250,00$ & $3.297 .750,00$ \\
& Pemupukan & $1.183 .750,00$ & $1.313 .500,00$ \\
& Penanaman & $2.468 .250,00$ & $2.664 .250,00$ \\
& Panen & $3.352 .250,00$ & $3.775 .500,00$ \\
5. Pengangkutan & $3.652 .000,00$ & $4.826 .500,00$ \\
6. Pengemasan & $565.250,00$ & $681.000,00$ \\
\hline Total & $\mathbf{2 4 . 9 2 7 . 0 5 3 , 0 0}$ & $\mathbf{2 7 . 4 7 6 . 9 4 2 , 0 0}$ \\
\hline
\end{tabular}

Tabel 5 menunjukkan biaya produksi per hektar yang dikeluarkan oleh petani kentang. Rata-rata biaya bibit yang dikeluarkan oleh petani varietas Superjohn dan Granola $L$ sama yaitu Rp.700.000,00 per karung, hal ini karena pada saat pertama kali petani kentang ingin membudidayakan kentang varietas Granola $L$ benih masih sangat terbatas, sehingga petani membeli bibit kentang Granola $L$ dari petani lainnya yang sudah lama memproduksi kentang Granola L. sama halnya dengan petani Superjohn, apabila dalam satu hektar petani kekurangan bibit mereka akan membeli bibit dari petani lainnya dengan harga yang sama.

Pajak yang dikeluarkan oleh petani kentang per hektar dalam satu tahun yaitu Rp.51.000,00. Sehingga perhitungan pajak untuk satu kali produksi petani varietas Superjohn di bagi 3 kali produksi dalam setahun dan di peroleh nilai sebesar Rp.17.000,00. sedangkan petani varietas Granola $L$ di bagi 4 kali produksi dalam setahun dan diperoleh nilai sebesar Rp.12.500,00.

Biaya pengolahan lahan yang dikeluarkan oleh petani kentang terdiri dari sewa traktor dan sewa bajak. Untuk menyewa traktor Rp.1.600.000,00/hektar. Namun petani lebih banyak menyewa bajak daripada traktor dengan biaya sewa Rp.1.200.000,00/hektar. Sehngga rata-rata biaya sewa alat yang dikeluarkan oleh 
petani Superjohn yaitu Rp.1.350.00,00, sedangkan petani varietas Granola $L$ Rp.1.332.500,00. Selanjutnya biaya pemupukan yang dikeluarkan petani kentang sedikit berbeda, karena penggunaan input pupuk yang digunakan berbeda, seperti jenis dan harga pupuk yang digunakan. Dan rata-rata biaya pestisida yang dikeluarkan oleh petani Granola $L$ sebesar Rp.463.900,00 dan petani Superjohn sebesar Rp.342.250,00.

Rata-rata tenaga kerja yang digunakan dalam satu kali produksi petani kentang varietas Superjohn sebanyak 83 orang dan petani varietas Superjohn sebanyak 94 orang. Biaya sewa buruh tani untuk. Biaya sewa buruh tani per hari rata-rata yaitu Rp.120.000,00/HOK, selanjutnya biaya pengolahan lahan yang dikeluarkan oleh petani varietas Superjohn sebesar Rp.2.945.250,00, sedangkan petani varietas Granola $L$ sebesar Rp.3.297.750,00. Pengolahan lahan yang dilakukan pleh tenaga kerja terdiri dari beberapa tahap yaitu pembersihan lahan, membajak lahan (pajeko), pembuatan bedengan (gundukan) dan setelah itu bibit siap ditanam. Dalam proses pengolahan lahan petani varietas Granola $L$ menggunakan tenaga kerja lebih banyak dengan maksud agar pengolahan lahan dilakukan lebih cepat dan selesai selama 4 hari, sedangkan untuk petani varietas Superjohn waktu untuk proses pengolahan lahan selama 7 hari.

Biaya sewa tenaga kerja untuk pemupukan dikeluarkan oleh petani Superjohn sebesar Rp.1.183.750,00, sedangkan petani varietas Granola $L$ sebesar Rp.1.313.500,00. Dalam proses pemupukan kedua petani mempunyai teknik perlakuan yang berbeda, rata-rata petani varietas Superjohn menanam terlebih dahulu menanam bibit kentang dan setelah 1-2 hari akan dilakukan pemupukan dasar yaitu organik, selanjutnya dilakukan pemupukan susulan ke 1 dan 2. Sedangkan ratarata petani varietas Granola $L$ melakukan teknik perlakuan dengan cara melakukan pemupukan terlebih dahulu sebelum tanam bibit, dan setelah itu dilakukan pemupukan susulan ke 1 dan 2.

Biaya sewa buruh tani untuk penanaman petani varietas Superjohn sebesar Rp.3.352.250,00 dan petani varietas Granola $L$ sebesar Rp.3.775.500,00. Dalam proses penanaman, umur bibit yang akan ditanam petani rata-rata berumur 2- 21/2 bulan dan ada yang melukakan doping dengan rata-rata berumur 1-2 minggu. Dopping dilakukan dengan maksud agar bibit lebih cepat ditanam, dan biasanya ini dilakukan apabila lahan sudah siap untuk ditanami.

Biaya tenaga kerja yangdikeluarkan dalam proses panen petani varietas Superjohn sebesar Rp.3.352.250,00 dan petani varietas Granola $L$ sebesar Rp.3.775.500,00. Rata-rata biaya yang dikeluarkan dalam proses panen cukup besar, hal ini karena dalam proses panen dibutuhkan lebih banyak tenanga kerja agar proses panen dilakukan dengan cepat. Biaya pengangkutan yang dikeluarkan oleh petani Superjohn sebesar Rp.3.652.000,00 dan petani varietas Granola $L$ sebesar Rp.4.826.500,00, pengangkutan dilakukan dengan motor yang disebut Kalero. Rata-rata biaya sewa kalero dalam satu kali jalan dari kebun menuju rumah yaitu sebesar Rp.25.000. Selain itu, etos kerja yang dilakukan tenaga kerja petani varietas Granola $L$ rata-rata 7 jam dengan 1 jam istirahat sedangkan tenaga kerja varietas Superjohn rata-rata 6 jam dengan 1 jam waktu istirahat.

Selanjutnya biaya pengemasan yang dikeluarkan oleh petani varietas Superjohn sebesar Rp.565.250,00 dan petani varietas Granola L sebesar Rp.681.000,00. Pengemasan dilakukan menggunakkan karung $60 \mathrm{~kg}$ dengan harga persatuan karung yaitu Rp.2.500,00.

\begin{tabular}{cccccc}
$\begin{array}{c}\text { Tabel 6. Rata-rata Produksi, Biaya Produksi, Penerimaan dan Pendapatan } \\
\text { Per Hektar }\end{array}$ \\
\hline Petani & $\begin{array}{c}\text { Produksi } \\
(\mathrm{Kg})\end{array}$ & $\begin{array}{c}\text { Harga } \\
(\mathrm{Rp})\end{array}$ & $\begin{array}{c}\text { Penerimaan } \\
(\mathrm{Rp})\end{array}$ & $\begin{array}{c}\text { Biaya } \\
\text { Produksi } \\
(\mathrm{Rp})\end{array}$ & $\begin{array}{c}\text { Pendapatan } \\
(\mathrm{Rp})\end{array}$ \\
\hline Superjohn & 13570 & $7.000,00$ & $94.990 .000,00$ & $24.927 .053,00$ & $70.062 .947,00$ \\
Granola L & 16358 & $7.000,00$ & $114.506 .000,00$ & $27.476 .942,00$ & $87.029 .058,00$ \\
\hline
\end{tabular}

Tabel 6 menunjukkan rata-rata produksi, biaya produksi, penerimaan dan pendapatan per hektar petani varietas Superjohn dan varietas Granola $L$, dapat dilihat bahwa pendapatan petani kentang varietas Granola $L$ lebih tinggi dibandingkan dengan petani varietas Superjohn. Hal ini disebabkan karena petani varietas Granola $L$ memiliki jumlah produksi lebih tinggi dibandingkan petani kentang varietas 
Superjohn, petani varietas Superjohn memiliki rata-rata produksi $13570 \mathrm{~kg}$ sedangkan petani varietas Granola $L$ rmemiliki rata-rata produksi $16358 \mathrm{~kg}$ dengan jumlah selisih produksi 2788 kg. Kentang varietas Granola $L$ memiliki potensi lebih tinggi dalam berproduksi dibandingkan kentang varietas Superjohn, selain itu varietas Granola $L$ memiliki umur produksi lebih pendek yaitu 3 bulan sedangkan varietas Superjohn memili umur produksi 4 bulan. Akan tetapi apabila perlakuan yang diberikan petani sama yaitu melakukan pemupukan pupuk dasar berupa pupuk kandang sebelum tanam bibit, kemungkinan produksi yang diperoleh akan sama.

Rata-rata biaya yang dikeluarkan oleh petani varietas petani varietas Superjohn yaitu sebesar Rp.24.927.053,00 dan rata-rata biaya produksi yang dikeluarkan petani Granola $L$ sebesar Rp.27.476.942,00. Dapat dilihat bahwa biaya produksi yang dikeluarkan petani varietas Granola $L$ lebih besar dibandingkan varietas Superjohn, walau petani varietas Granola $L$ mengeluarkan biaya produksi lebih besar, namun dapat diimbangi dengan penerimaan yang besar yaitu sebesar Rp.114.506.000,00 dan penerimaan yang diperoleh petani varietas Superjohn sebesar Rp.94.990.000,00.

Hasil dari penelitian ini adalah petani varietas Granola $L$ memiliki produksi yang tinggi dan memperoleh penerimaan yang tinggi dalam satu kali produksi, maka petani varietas Granola $L$ memperoleh pendapatan yang lebih besar dibandingkan petani varietas Superjohn yaitu sebesar Rp.87.029.058,00, sedangkan petani varietas Superjohn memperoleh pendapatan dalam satu kali produksi sebesar Rp.70.062.947,00. Dapat dilihat bahwa terdapat perbandingan pendapatan usahatani antara varietas Superjohn dan varietas Granola $L$ dengan selisih sebesar Rp.16.960.111,00.

Kentang varietas Granola $L$ memiliki kemampuan berproduksi lebih tinggi, memiliki banyak umbi dalam satu pohon kentang dan memiliki umur yang lebih pendek, akan tetapi kentang varietas Granola $L$ menggunakan lebih banyak tenaga kerja dalam satu kali produksi. Sedangkan kentang varietas Superjohn memiliki ukuran yang besar dan penggunaan tenaga kerja yang lebih sedikit, memiliki umur lebih panjang dan memiliki jumlah produksi lebih kecil, akan tetapi apabila dilakukan perlakuan yang sama, kentang varietas Superjohn dapat memiliki jumlah produksi yang sama dengan varietas Granola L. Menurut Soekartawi (1991) dalam (Hidayat, 2014) faktor produksi dalam produksi pertanian menentukan besar kecilnya produksi yang akan diperoleh. Bibit dan varietas merupakan faktor biologis yang mempengaruhi produksi. Seperti halnya kentang varietas Granola $L$ yang memiliki potensi produksi lebih tinggi yaitu berkisar 26 ton/ha dan kentang varietas Superjohn memiliki produksi antara 10-17 ton/ha.

Setelah dilakukan pengujian menggunakan uji statistik dengan Program MINITAB, perhitungan pendapatan per hektar diperoleh nilai signifikan P-Value sebesar 0,01 pada $\alpha 5 \%$ yaitu $0,01<0,05$. Hal ini berarti $\mathrm{H} 0$ ditolak dan $\mathrm{H} 1$ teruji kebenarannya bahwa ada perbedaan pendapatan usahatani kentang varietas Superjohn dan varietas Granola $L$ di Desa Pinasungkulan Utara Kecamatan Modoinding.

\section{KESIMPULAN DAN SARAN}

\section{Kesimpulan}

Hasil penelitian menunjukkan bahwa rata-rata pendapatan petani varietas Superjohn adalah Rp.70.062.947,00 lebih rendah dibandingkan dengan rata-rata pendapatan yang diperoleh petani varietas Granola L sebesar Rp.87.029.058,00. Dapat dilihat bahwa rata-rata selisih pendapatan yang diperoleh antara kedua varietas adalah sebesar Rp.16.960.111,00. Berdasarkan hasil uji statistik dengan Program MINITAB, perhitungan pendapatan per hektar diperoleh nilai signifikan $\mathrm{P}$-Value sebesar 0,01 pada $\alpha$ $5 \%$ yaitu $0,01<0,05$. Hal ini berarti $\mathrm{H}_{0}$ ditolak dan $\mathrm{H}_{1}$ teruji kebenarannya bahwa ada perbedaan signifikan antara pendapatan usahatani kentang varietas Superjohn dan varietas Granola L. Hal ini disebabkan karena pendapatan yang diperoleh petani varietas Granola $L$ lebih tinggi dibandingkan petani varietas Superjohn. 


\section{Saran}

Untuk petani benih varietas Superjohn sebaiknya memperhatikan perlakuan yang diberikan pada saat membudidayakan tanaman kentang, seperti teknik pemberian pupuk dasar. Selain itu, penggunaan tenaga kerja lebih di tingkatkan, agar dapat menghasilkan produksi yang lebih efesien.

Untuk pemerintah sebaiknya dapat lebih mengembangkan benih kentang varietas Granola L, khususnya pada Balai Penelitian Tanaman Sayuran (Balista) dan Balai Benih Induk. Karena masih terbatasnya benih kentang varietas Granola $L$ di Balai Benih induk Kecamatan Modoinding yang bertempat di Desa Linelean.

\section{DAFTAR PUSTAKA}

Badruzaman, J, 2015. "Analisis Komparatif Non Performance Financing Sebelum Dan Sesudah Diterbitkannya Fatwa Nomor 84/Dsn-Mui/Xii/2012 (Sensus Pada Empat Bank Syariah Di Tasikmalaya)", Sustainable Competitive Advantage (SCA), Vol. 5, No. 1:1-15.

Badan Pusat Statistik Kabupaten Minahasa Selatan, 2016. Kecamatan Modoinding dalam Angka 2015. Kabupaten Minahasa Selatan.

Balai Penyuluhan Pertanian, Perikanan Dan Kehutanan, 2015. Kecamatan Modoinding. Kabupaten Minahasa Selatan. Amurang.

Arfah, Y., Rauf, R. A., \& Sulaeman, H, 2013. "Analisis Komparatif Pendapatan Usahatani Padi Sawah Sistem Tabela Dan Sistem Tapin (Di Desa Dolago Kecamatan Parigi Selatan Kabupaten Parigi Moutong)", Jurnal Agrotekbis, Vol. 1, No. 3:244-249.

Duriat, 2006. Penerapan Teknologi PHT Pada Tanaman Kentang. Balai Penelitian Tanaman Sayuran. Bandung.
Hakim, R. M. 2013. Analisis Perbandingan Usahatani Kentang Tiga Desa di Kecamatan Pasirwangi, Kabupaten Garut. Skripsi. Fakultas Ekonomi dan Manajemen. Institut Pertanian Bogor. Bogor.

Hidayat, F., \& Muis, A, 2014. "Analisis Komparatif Produksi Dan Pendapatan Usahatani Padi Sawah Irigasi Setengah Teknis Dan Irigasi Desa Di Desa Pakuli Kecamatan Gumbasa Kabupaten Sigi", Jurnal Agrotekbis, Vol. 2, No. 2:193198.

Juliandi, Azuar, Irfan \& S. Manurung. 2014. Metodelogi Penelitian Bisnis. Penerbit UMSU PRESS. Medan.

Lumintang, F. M, 2013. “Analisis Pendapatan Petani Padi Di Desa Teep Kecamatan Langowan Timur", Jurnal Riset Ekonomi, Manajemen, Bisnis Dan Akuntansi, Vol. 1, No. 3:991-998.

Luntungan, A, 2012. “Analisis Tingkat Pendapatan Usaha Tani Tomat Apel Di Kecamatan Tompaso Kabupaten Minahasa", Jurnal Pembangunan Ekonomi dan Keuangan Daerah, Vol. 7, No. 3:3-4.

Mariani, N. 2011. “Analisa Perbandingan Pendapatan dan Keuntungan Usahatani Kentang(Solanum tuberosum L.) antara Menggunakan Benih Kultur Jaringan Bersertifikat (G4) dengan Benih Lokal di Kanagarian Batagak Kecamatan Sungai Puar Kabupaten Agam”. Skripsi. Fakultas Pertanian, Universitas Andalas. Padang.

Palendeng, J. H. 2010. “Analisis Keragaman Genetik Tanaman Kentang (Solanum tuberosum L) varietas "Superjohn", Granola, dan Atlantik berdasarkan Penanda RAPD (Randomly Amplified Polymorphic DNA)". Tesis Program Pascasarjana UNSRAT. Manado. 
Ridwan H.K, Nurmalinda, Sabari \& Y. Hilman. 2010. "Analisis Finansial Penggunaan Benih Kentang G4Bersertifikat dalam Meningkatkan Pendapatan Usahatani Petani Kentang", Jurnal Hortikultura, Vol. 20, No. 2:196-206.

Runtunuwu D.S, Rogy, J.E.X \& Palendeng, J.H. 2011. "Identifikasi Varietas Kentang "Superjohn" Berdasarkan Penanda RAPD (Random Amplified Polymorphic DNA)". Tesis Program Pascasarjana UNSRAT. Manado.

Samadi, Budi. 2007. Kentang dan Analisis Usaha Tani. Penerbit Kanisius. Yogyakarta.

Setiadi. 2009. Budi Daya Kentang. Penerbit Penebar Swadaya. Jakarta.

Soekartawi. 2002. Analisis Usahatani. Penerbit UI Press. Jakarta.

Sugiyono. 2010. Statistik Untuk Penelitian. Penerbit CV. Alfabeta. Bandung.

Arifin, M.Z. \& Salmiah, E. 2014. "Analisis Harga Pokok Tandan Buah Segar (Tbs), Cpo Dan Inti Sawit Di Kebun Gunung Bayu PT. Perkebunan Nusantara Iv Kabupaten Simalungun". Journal On Social Economic Of Agriculture And Agribusiness. Vol. 2, No. 11:1-10. 